\title{
FATTY ACID COMPOSTION OF SELECTED VIETNAMESE BISCUITES INCLUDING TRANS-ISOMERS
}

\author{
Hoang Quoc Tuan", 2, *, Vu Hong Son ${ }^{1}$, Nguyen Thi Minh Tu ${ }^{1}$ \\ ${ }^{1}$ Hanoi University of Science and Technology, School of Biotechnology and Food Technology, \\ Department of Quality Management, Hanoi, Vietnam \\ ${ }^{2}$ University of Natural Resources and Life Sciences, \\ Department of Food Science and Technology Institute of Food Science, Vienna, Austria
}

"Email: tuanhqibft@gmail.com ; tuan.hoangquoc@hust.edu.vn

Received: 10 June 2013, Accepted for publication: 7 November 2013

\begin{abstract}
In this study, fatty acid compositions including trans-isomers contents of selected Biscuits products produced by Vietnamese confectionery companies and imported products purchased from Hanoi markets were determined by gas chromatography. Palmitic acid and oleic acid were the most abundant, with concentrations ranged from $21 \%$ to $52 \%$, and $23 \%$ to $43 \%$, respectively, and followed by linoleic acid, lauric acid, myristic acid. The saturated, cismonounsaturated and cis-polyunsaturated fatty acid contents were within ranges of $37 \%-75 \%$, $18 \%-43 \%, 0.4-26 \%$ of total fatty acid methyl ester, respectively. Trans-fatty acids were identified in all samples excepted brands B3, B13, B17, B24*, and the contents ranged from $0.07 \%$ to $7,16 \%$. A considerable variability in fatty acid composition of biscuits which indicated that different types of fats and oils were used for production of selected Vietnamese biscuits and imported products was showed by these results got from the study.
\end{abstract}

Keywords: Trans-fatty acids, biscuits, fatty acid composition

\section{INTRODUCTION}

Coronary heart disease (CHD) is still main cause of death and disability in many countries around the world, not excepting Vietnam. According to Vietnam Cardiovascular Institute, the ratio of CHD patient above 25 years old had increased eightfold from $2 \%$ in 1960 to $16.3 \%$ in 2003 and it rapidly increases year by year. Several multiple risk factors were reported that act both independently and jointly. Among dietary factors, total amount of fat and the type of fats intake in the diet play an important role in determining risk of CHD [1].

It has been demonstrated for many years that a high intake of saturated fat contributes to the development of CHD [2]. Several researches have also indicated that a high intake of trans fatty acids (TFA) raises low density lipoprotein (LDL) cholesterol and lowers high density lipoprotein (HDL) cholesterol, affecting the LDL/HDL cholesterol ratio in a way that is

\footnotetext{
*: The names of biscuit brands were coded in order to keeps privacy off biscuit companies.
} 
unfavourable compared with all other fatty acids [3]. Moreover, trans fats have been reported to raise lipoprotein (a) and plasma triglyceride levels that are independently associated with the increased risk of CHD [4 - 9].

There are four main TFA sources: industrial hydrogenation, microbial transformation of unsaturated fatty acids in ruminants, heating and frying above $180{ }^{\circ} \mathrm{C}$, and deodorization of edible oils [10 - 12].

Because of the different in isomers between trans fatty acid from animal and edible oils sources they seem to have difference diverse effects on health. While TFA from edible oils origin are associated with an increased risk for coronary heart disease [13], no relation has been observed between TFA of ruminant origin and heart disease [14 - 16].

Basically, fats are probably the most important ingredients used in the manufacture of biscuits. They are the third largest component, after flour and sugar [17]. Fats are the principle ingredient responsible for adding a rich quality to cookies [18] and in a biscuit formulation has numerous roles. It interacts with other ingredients to develop texture, mouth feel and overall sensation of lubricity of the product, thereby affecting the rheological properties of baked biscuits [19]. For biscuits manufacturing, the choice of a better kind of lipid often depends on technological and economic parameters, without considering the nutritional implications, especially small private companies or/and private enterprises. For this reason, it is necessary to evaluate the quality and quantity of fat.

\section{MATERIALS AND METHODS}

\subsection{Sampling}

Three package units of each brand of Biscuits were purchased from local supermarkets which date of production are labeled from February 2011 to July 2011. Each brand was coded with number from B1 to B39. Lot numbers were checked to ensure that each unit belonged to a different lot. Samples were selected to include the major manufacturers and private company of the Biscuits in Vietnam and imported products. The analyses were carried out in triplicate.

\subsection{Methods}

\section{Lipid Extraction}

Lipids were extracted from biscuits according to the method as described in the studied of Nathalie Vingering et al. [20]. In brief, the biscuits were ground, and a $3 \mathrm{~g}$ was weighed to the nearest $1 \mathrm{mg}$ in to a centrifuge tube. Lipids were then extracted by using a $30 \mathrm{~mL}$ hexane/isopropanol $(3: 2, \mathrm{v} / \mathrm{v})$ mixture. After centrifugation at $1100 \mathrm{rpm}$ for $10 \mathrm{~min}$, the upper layer was collected and filter through a $\mathrm{Na}_{2} \mathrm{SO}_{4}$ column (prepared by using Pasteur pipette which was added wood glass and $\mathrm{Na}_{2} \mathrm{SO}_{4}$ ). The solvent was removed using a rotational evaporator at $40{ }^{\circ} \mathrm{C}$. The extracted was then dried at a temperature of $<40{ }^{\circ} \mathrm{C}$ under nitrogen. The lipid amount was then collected for analyzing fatty acid composition.

\section{Transmethylation and analysis of fatty acids}

Ten milligram of sample was converted to fatty acid methyl ester (FAME) by dissolving in hexane and $2 \mathrm{M}$ methanolic $\mathrm{KOH}$ in a tube ( $2 \mathrm{ml}$ for each solvent). Then, the tube was shaken vigorously for 2 minutes at room temperature in the vortex. The supernatant was transferred to 
other test tube and was added sodium sulfate, after that upper layer organic solvent was collected for GC analysis.

The fatty acid composition was identified in triplicate by separating the FAME on a GCMS equipment with BPX-70 column $(30 \mathrm{~m} \times 0.25 \mathrm{~mm})$. The temperature program was $5 \mathrm{~min}$ at $60{ }^{\circ} \mathrm{C}$ and then it was increased to $165^{\circ} \mathrm{C}$ with $15^{\circ} \mathrm{C} / \mathrm{min}$ and held at this temperature for $1 \mathrm{~min}$, and then increased to $225{ }^{\circ} \mathrm{C}$ with $2{ }^{\circ} \mathrm{C} / \mathrm{min}$, held for $1 \mathrm{~min}$. The injection temperature was $250{ }^{\circ} \mathrm{C}$, split flow $(\mathrm{ml} / \mathrm{m})$ was 100 and the split ration was $100: 1(20)$.

\section{Ag+thin layer chromatography fractionation}

Total fatty acid methyl esters were fractionated by silver-ion thin layer chromatography. In brief, pre-coated silica gel 60 high performances TLC was impregnated by dipping in $10 \%$ (wt/vol) $\mathrm{AgNO}_{3}$ solution in acetonitrile for $20 \mathrm{~min}$. The plate was then left for 5 min to dry at $110{ }^{\circ} \mathrm{C}$ in an oven. Total fatty acid methyl esters were applied onto the plate in the narrow band, and developed in hexane/diethyl ether $(90: 10, \mathrm{vol} / \mathrm{vol})$ solvent. After the developing finished, the plate was then air-dried and sprayed with a $0.2 \%$ (wt/vol) $95 \%$ ethanolic solution of 2',7'dichlorofluorescein, examined under UV light and marked. The bands were scraped off, then poured into a short column of anhydrous sodium sulfate (prepared in a Pasteur pipette, plugged with a small of cotton wool), and extracted with diethyl ether/hexane (50:50 vol/vol), and then analyzed by GC (20).

\section{RESULTS AND DISCUSSION}

Table 1 showed fatty acid composition of biscuits. Among saturated fatty acids, palmitic acid was the most abundant fatty acid in all samples; its concentration was from $21 \%$ to $52 \%$, followed by stearic acid $(3,2 \%-7,7 \%)$. The presence of high amounts of palmitic acid indicated the presence of palm oil. Among unsaturated fatty acids, oleic acid was the next most main fatty acid; accounting for from $23 \%$ to $43 \%$, followed by linoleic acid, with concentration from $4 \%$ to $25 \%$, Various studies [21,22] have suggested that saturated fatty acids with chain length of C12:0-C16:0 are atherogenic, stearic acid is neutral, and oleic and polyunsaturated fatty acids have a lipid lowering effect.

Figures 1 shows the minimum, maximum, and mean value of the sums of saturated fatty acids (SFA), cis-monounsaturated fatty acids (cis-MUFA), cis-polyunsaturated fatty acids (cisPUFA), and trans fatty acid (TFA) of the lipid fraction of the examined biscuits. Total saturated fatty acids (SFA) were significantly higher in brand B22 (75.3\%), followed by brand from B12 to B6. The lowest concentration of SFA was identified brand B19 (37.9\%). SFA represented $51.7 \%$ of the total, as a mean (range: 37.9-75.3\%). The content of cis-polyunsaturated fatty acid ranged from $0.4 \%$ to $26.3 \%$, which are significantly higher in brand B19 (26.3\%), B21 (23.5 $\%), \mathrm{B} 20(19.4 \%)$ and B18 (18.6\%), and the lowest concentration was found in brand B30 (0.4 $\%)$. The low PUFA content indicates the use of solid fats; often obtained by hydrogenation of refined vegetable oils. Cis-polyunsaturated fatty acids have beneficial effects on both normal heath and chronic diseases, such as regulation of lipid level [23] cardiovascular [24] and immune functions [25]. 


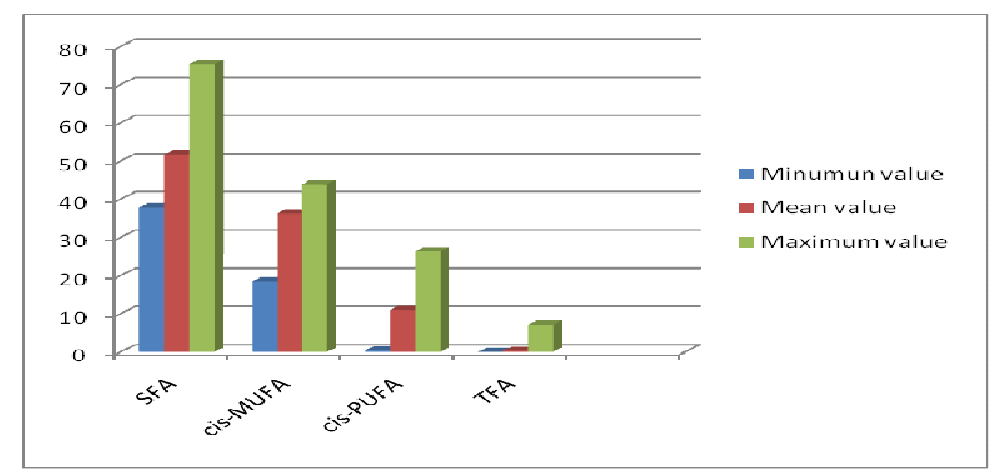

Figure 1. Mean, minimum, maximum value of the sums of saturated fatty acids (SFA), cis-monounsaturated fatty acids (cis-MUFA), trans fatty acid (TFA), and cis-polyunsaturated fatty acids (cis-PUFA) of lipid fraction of the examined biscuits.

Monounsaturated content ranged from $18.5 \%$ to $43.9 \%$. Among the cis-monounsaturated fatty acids, oleic acid was the most represented. Oleic acid is considered to be responsible for lowering the LDL cholesterol levels. For concluding the quality and safety of fat in biscuits, however, other studies should be carry out for determining some parameters such as peroxides values, p-anisidine values. According to the study of Angela A. Rivellese et al. [26] in which the results shows that high SFA diets negatively influence the cholesterol and triacylglycerol content of LDL lipoproteins and that, on the contrary, high MUFA diets have beneficial effects on LDL cholesterol and triacylglycerols. As the recommendation of Department of Health (UK) [27], the minimal ratio value of PUFA/SFA should be 0.45 . In this study the cis-PUFA/SFA ratio ranged from 0.01 to 0.7 , and the mean was 0.24 which is much lower than the recommended value. In this study, all peaks appearing between the C18:0 and C18:1 (9c) major peaks were quantified as the trans $18: 1$ group, even if they did not contain all the trans-C18:1 isomers as the results which were shown in study of Nathalie Vingering et al [20].

The amount of total TFA in the samples ranged from $0.00 \%$ to $7.16 \%$ of total fatty acid methyl ester and the mean was $0.54 \%$. To comparison the trans fatty acids among brands, total trans content was significant higher in brands B30 and B31, 7.16\% and $1.12 \%$, respectively. The interesting thing about that is the prices of these brands were significantly higher than all the rest of samples. The significant lower $(<0.1 \%)$ was identified with brands B2 and B5, 0.07\%, and $0.09 \%$, respectively. The trans isomers were not identified in brands B3, B11, B13, B17 and B24. The trans fatty acids comprise isomers of 18:1 and 18:2, and trans 18:2 isomers were the major group of TFA present in all the analyzed brands, representing $80 \%$ of total trans isomers. Total mono-trans 18:2 isomer (c,t and t,c) content ranged from $0.07 \%$ to $5.48 \%$ of total fatty acid methyl esters, this being the most prevalent group of trans polyunsaturated acid. The trans 18:1 isomer were found at very low levels $(0.05-1.53 \%$ of total fatty acid methyl esters). Partially hydrogenated vegetable oils mainly contained 8t-to $11 \mathrm{t}-18: 1$ isomers whereas milk fat contained significant 12t-to16t-18:1 isomer amounts (17). Trans 18:3 isomer content was not found in all samples. Only two samples (among all samples) presented a high trans fatty acid content, showing that the food industry followed the scientific advice and changed their process to decrease trans-fat production. 
Table 1. Fatty acid composition and trans isomer content of the lipid fraction of the examined biscuits

\begin{tabular}{|c|c|c|c|c|c|c|c|c|c|c|c|c|c|c|c|c|c|c|}
\hline ple & $\begin{array}{l}\text { O̊ } \\
\dot{0} \\
0\end{array}$ & $\begin{array}{l}0 \\
0 \\
0 \\
0\end{array}$ & $\begin{array}{l}\stackrel{0}{\dot{j}} \\
\frac{0}{0}\end{array}$ & $\begin{array}{l}\stackrel{0}{\dot{+}} \\
\dot{U}\end{array}$ & فํ. & $\begin{array}{l}0 \\
\dot{0} \\
\dot{0}\end{array}$ & $\frac{\pi}{0} \frac{1}{0}$ & $\frac{\overline{0}}{0}$ & $\frac{\grave{\lambda}}{\hat{N}}$ & $\stackrel{0}{\infty}$ & 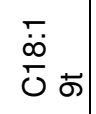 & $\underset{\bar{\infty}}{\bar{\infty}} \pm$ & $\frac{\bar{\infty}}{\overline{0}}$ & $\frac{\bar{\infty}}{0} \stackrel{0}{\sigma}$ & 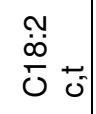 & 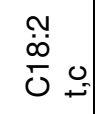 & \begin{tabular}{lll} 
& \\
$\ddot{\infty}$ & 0 \\
\hdashline & 0 \\
0 & 0
\end{tabular} & \\
\hline B1 & nd & nd & 0.74 & 0.98 & nd & 46.85 & nd & 0.09 & 0.08 & 3.74 & nd & 0.05 & 37.12 & 0.34 & 0.17 & 0.19 & 9.40 & \\
\hline B2 & 2.03 & 1.76 & 15.03 & 5.95 & nd & 22.44 & nd & 0.06 & 0.04 & 3.26 & nd & nd & 29.01 & 0.23 & 0.04 & 0.03 & 18.47 & 0 \\
\hline B3 & 1.80 & 1.57 & 13.23 & 5.52 & nd & 37.19 & nd & 0.08 & nd & 3.38 & nd & nd & 29.09 & 0.29 & nd & nd & 7.37 & 0 \\
\hline B4 & nd & nd & 0.26 & 0.83 & nd & 49.04 & nd & 0.09 & 0.05 & 3.58 & nd & nd & 36.04 & 0.35 & 0.12 & 0.12 & 9.50 & \\
\hline B5 & nd & nd & 0.25 & 0.80 & nd & 40.02 & nd & 0.11 & 0.05 & 3.48 & nd & nd & 42.37 & 0.38 & 0.05 & 0.04 & 12.04 & 0 \\
\hline B6 & 1.74 & 2.48 & 13.29 & 11.41 & 0.45 & 32.10 & 0.08 & 0.84 & 0.19 & 6.15 & 0.12 & 0.34 & 23.28 & 0.32 & nd & nd & 4.49 & 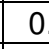 \\
\hline B7 & nd & nd & 0.30 & 0.92 & 0.04 & 46.00 & nd & 0.09 & 0.05 & 3.52 & nd & 0.23 & 37.64 & 0.35 & 0.11 & 0.11 & 10.34 & 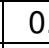 \\
\hline B8 & nd & nd & 0.29 & 1.07 & 0.05 & 38.92 & nd & 0.15 & 0.06 & 3.37 & nd & 0.07 & 43.35 & 0.43 & 0.07 & 0.08 & 11.77 & 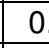 \\
\hline B9 & nd & nd & 0.21 & 0.81 & nd & 39.81 & nd & 0.15 & nd & 3.11 & nd & nd & 43.01 & 0.44 & 0.1 & 0.12 & 11.98 & 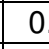 \\
\hline B10 & nd & nd & 0.11 & 0.74 & nd & 52.95 & nd & 0.07 & 0.07 & 3.27 & nd & nd & 32.10 & 0.33 & 0.13 & 0.17 & 9.75 & 0. \\
\hline B11 & nd & nd & 0.38 & 0.83 & nd & 46.41 & nd & 0.10 & 0.05 & 3.50 & nd & nd & 37.88 & 0.36 & nd & nd & 10.23 & 0 \\
\hline B12 & 65 & 2.52 & 11.89 & 11.03 & 0.51 & 33.58 & 0.09 & 0.89 & 0.21 & 6.59 & 0.06 & 0.33 & 23.31 & 0.31 & nd & nd & 3.96 & 8 \\
\hline B13 & nd & nd & 6 & 0.81 & nd & & nd & 11 & nd & 9 & nd & nd & .40 & 0.41 & 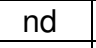 & nd & 34 & 0. \\
\hline B14 & 38 & 0.33 & 3.29 & 2.54 & 0.13 & 39.88 & 0.08 & 0.4 & 1.27 & 7.46 & 0.22 & 0.23 & 32.11 & 0.7 & 0.1 & 0.12 & 9.13 & 0. \\
\hline B16 & nd & nd & d & 0.91 & nd & 46.46 & 0.09 & 0.09 & d & 4.25 & nd & nd & 35.33 & 0.63 & 6 & 3 & 56 & 0 \\
\hline B17 & nd & nd & 0.15 & nd & 0.89 & 37.2 & nd & 0.19 & 0.04 & 4.3 & nd & nd & 39.83 & 0.77 & 0.08 & 0.05 & 15.78 & 0. \\
\hline B18 & nd & nd & 0 & 0.68 & nd & 37.55 & nd & nd & 0.12 & 3.56 & nd & nd & 41.72 & 0.81 & & nd & 5.02 & \\
\hline B19 & nd & nd & 0.16 & 0.8 & nd & 36.7 & nd & 0.15 & 0.09 & 4.12 & nd & nd & 40.4 & 0.85 & 0.12 & 0.13 & 15.9 & - \\
\hline B20 & 0.29 & 0.23 & 2.19 & 1.29 & nd & 27.86 & nd & 0.13 & 0.07 & 4.42 & nd & nd & 33.99 & 0.93 & 0.22 & 0.19 & .99 & 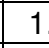 \\
\hline B21 & nd & nd & 0.14 & 0.71 & nd & 40.87 & nd & 0.1 & 0.14 & 4.15 & nd & nd & 32.03 & 0.67 & 0.4 & 0.39 & 19.17 & - \\
\hline B22 & nd & nd & 0.18 & 0.58 & nd & 33.52 & nd & 0.1 & 0.1 & 3.72 & nd & nd & 35.73 & 0.83 & 0.18 & 0.23 & 23.35 & 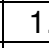 \\
\hline B23 & 1.54 & 1.47 & 20.28 & 8.17 & 0.08 & 25.93 & nd & 0.25 & 0.12 & 17.52 & 0.21 & 0.29 & 17.89 & 0.34 & nd & nd & 5.53 & 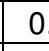 \\
\hline B27 & nd & nd & 0.09 & 0.88 & nd & 46.88 & nd & 0.1 & 0.1 & 6.02 & 0.07 & nd & 33.86 & 0.56 & 0.1 & 0.1 & 10.82 & 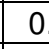 \\
\hline B28 & 1.53 & 1.24 & 14.83 & 7.64 & nd & 21.45 & nd & 0.17 & 1.21 & 2.94 & nd & nd & 36.14 & 0.99 & nd & nd & 11.55 & \\
\hline B29 & $\mathrm{n}$ & nd & 0.12 & 0.77 & nd & 42.83 & nd & 0.13 & nd & 5.15 & nd & nd & 37.35 & 0.66 & 0.11 & 0.1 & 12.34 & 0 \\
\hline B31 & 0.52 & 0.45 & 4.5 & 2.39 & nd & 43.41 & nd & 0.1 & 0.26 & 4.56 & nd & nd & 31.75 & 0.55 & 0.08 & 0.08 & 10.78 & 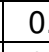 \\
\hline B32 & 0.41 & 1.13 & 1.66 & 5.99 & 0.5 & 34.7 & 0.13 & 1.11 & 0.27 & 7.7 & 0.08 & 0.43 & 31.51 & 0.82 & 0.15 & 0.08 & 10.47 & $\underline{U}$ \\
\hline B33 & nd & nd & 0.09 & 0.81 & nd & 52.09 & nd & 0.07 & 0.18 & 4.47 & nd & nd & 32.33 & 0.38 & 0.05 & 0.05 & 9.00 & 7 \\
\hline B36 & 0.55 & 1.55 & 1.86 & 8.91 & 0.84 & 34.36 & 0.14 & 0.92 & 0.5 & 10.95 & 0.14 & 1.38 & 28.69 & 0.37 & 5.16 & 0.34 & 0.39 & \\
\hline B38 & 0.46 & 0.42 & 4.13 & 2.65 & nd & 36.05 & nd & 0.4 & 0.32 & 7.93 & 0.34 & 0.52 & 37.96 & 0.59 & 0.14 & 0.1 & 7.53 & \\
\hline B39 & 0.64 & 0.95 & 14.56 & 7.02 & 0.11 & 34.47 & nd & 0.16 & nd & 7.16 & 0.12 & 0.22 & 28.34 & 0.33 & nd & nd & 5.59 & \\
\hline
\end{tabular}


These results showed that the amount of trans monounsaturated and polyunsaturated in selected Vietnamese biscuits is quite different among the analyzed samples. It could be explained by using the different ingredients in quality, such as shortening and the differences in drying process condition, such as temperature, heat source (gas or coal), equipment designs. All of these factors affect the biscuits except one brand contain negligible proportions of trans fatty acids, both with monounsaturated and polyunsaturated fatty acids.

\section{CONCLUSION}

The data obtained in this study, had presented the fatty acids composition of selected Vietnamese biscuits and imported products. The results show that the amount of trans monounsaturated and polyunsaturated fatty acids in all the brands studied were very low or even undetectable except one brand. The results, however, also shown that selected Biscuits contain large amounts of saturated fatty acids and low amounts of cis-polyunsaturated fatty acids, which mainly palmitic acid, oleic acid and linoleic acids. Therefore, it would be necessary to keep monitoring and inspecting content of atherogenic fatty acids in biscuits.

Acknowledgement. The authors would like to thank Dr. Matthias Schreiner for accepting to carry out this study at his laboratory (Division of Food Chemistry, Department of Food Sciences and Technology, University of Natural Resources and Life Sciences, Vienna), and for his helpful information and advice. The TRIG2 project provided funding for this work.

\section{REFERENCES}

1. Hu F. B., Manson J. E., and Willett W. C. - Types of dietary fat and risk of coronary heart disease: a critical review, J. Am. Coll. Nutr. 20 (2001) 5-19.

2. Ascherio A., Rimm E. B., Giovannucci E. L., Spiegelman D., Stampfer M., and Willett W. C. - Dietary fat and risk of coronary heart disease in men: cohort follow up study in the United States, BMJ 313 (1996) 84-90.

3. Bhattacharya A., Banu J., Rahman M., Causey J., and Fernandes G. - Biological effects of conjugated linoleic acids in health and disease, J. Nutr. Biochem. 17 (2006) 789-810.

4. Ascherio A., Katan M. B., Zock P. L., Stampfer M. J., and Willett W. C. - Trans fatty acids and coronary heart disease, N. Engl. J. Med. 340 (1999)1994-1998.

5. Clarke R., and Lewington S. - Trans fatty acids and coronary heart disease, BMJ 333 (2006) 214.

6. McKeigue P. - Trans fatty acids and coronary heart disease: weighing the evidence against hardened fat, Lancet 345 (1995) 269-270.

7. Vijver van de L. P., Poppel van, G., Houwelingen van A., Kruyssen D. A., and Hornstra G. - Trans unsaturated fatty acids in plasma phospholipids and coronary heart disease: a case-control study, Atherosclerosis 126 (1996) 155-161.

8. Woodside J. V., McKinley M. C., and Young I. S. - Saturated and trans fatty acids and coronary heart disease, Curr. Atheroscler. Rep. 10 (2008) 460-466.

9. Zaloga G. P., Harvey K. A., Stillwell W., and Siddiqui R. - Trans fatty acids and coronary heart disease, Nutr. Clin. Pract. 21 (2006) 505-512. 
10. Kepler C. R., Hirons K. P., McNeill J. J., and Tove S. B. - Intermediates and products of the biohydrogenation of linoleic acid by Butyrinvibrio fibrisolvens, J. Biol. Chem. 241 (1966) 1350-1354.

11. Valenzuela A., and Morgado N. - Trans fatty acid isomers in human health and in the food industry, Biol. Res. 32 (1999) 273-287.

12. Wolff R. L. - Cis-trans isomerization of octadecatrienoic acids during heating. Study of pinolenic (cis-5,cis-9,cis-12 18:3) acid geometrical isomers in heated pine seed oil, Journal of the American Oil Chemists' Society 71 (1994) 1129-1134.

13. Mozaffarian D., Katan M. B., Ascherio A., Stampfer M. J., and Willett W. C. - Trans fatty acids and cardiovascular disease, N. Engl. J. Med. 354 (2006) 1601-1613.

14. Jakobsen M. U., Bysted A., Andersen N. L., Heitmann B. L., Hartkopp H. B., Leth T., Overvad K., and Dyerberg J. - Intake of ruminant trans fatty acids and risk of coronary heart disease-an overview, Atheroscler. Suppl. 7 (2006) 9-11.

15. Jakobsen M. U., Overvad K., Dyerberg J., and Heitmann B. L. - Intake of ruminant trans fatty acids and risk of coronary heart disease, Int. J. Epidemiol 37 (2008) 173-182.

16. Pietinen P., Ascherio A., Korhonen P., Hartman A. M., Willett W. C., Albanes D., and Virtamo J. - Intake of fatty acids and risk of coronary heart disease in a cohort of Finnish men, The Alpha-Tocopherol, Beta-Carotene Cancer Prevention Study, Am. J. Epidemiol. 145 (1997) 876-887.

17. Precht D. J. M. - Trans fatty acids: Implications for health, analytical methods, incidence fats and intake, Nahrung 39 (1995) 343-374.

18. O'Brien C. M., Neville D. P., Keogh M. K., Arendt E. K. - Effect of varying the microencapsulation process on the functionality of hydrogenated vegetable fat in short dough biscuits, Food Research International 36 (2003) 215-221.

19. Jissy J. K. L. - Effect of fat-type on cookie dough and cookie quality, Journal of Food Engineering 79 (2007) 299-305.

20. Ledoux N. V. A. M. - Use of BPX-70 $60 \mathrm{~m} \mathrm{GC} \mathrm{columns} \mathrm{for} \mathrm{screening} \mathrm{the} \mathrm{fatty} \mathrm{acid}$ composition of industrial cookies, European Journal of Lipid Science and Technology 111 (2009) 669-677.

21. Hu F. B., Manson M. J. S., Ascherio A., Colditz G. A., Speizer F. E., Hennekens C. H., Willet W. C. - Dietary saturated fats and their food sources in relation to the risk of coronary heart disease in women, Journal of the American Oil Chemists' Society 70 (1999) 1001-1008.

22. Aro A., Partanen M. J. R., Salminen I., Mutanen M.,. -Stearic acid, trans fatty acids, and dairy fat effects on serum and lipoprotein lipids, apolipoproteins, lipoprotein (a) and lipid transfer proteins in healthy subjects, Journal of the American Oil Chemists' Society $\mathbf{6 5}$ (1997) 1419-1426.

23. Mori T. A., Puddey I. B., Watts G. F., O'Neal D. N., Best J. D., Beilin J. L. - Purified eicosapentaenoic and docosahexaenoic acids have differential effects on serum lipids and lipoproteins, LDL particle size, glucose, and insulin in mildly hyperlipidemic men, The American Journal of Clinical Nutrition 71 (2000) 1085-1094.

24. Kris-Etherton P. M., Appel L. J. - Fish consumption, fish oil, omega-3 fatty acids, and cardiovascular disease, Circulation 106 (2002) 2747-2757. 
25. Hwang D. - Fatty acids and immune responses a new perspective in searching for clues to mechanism, Annual Review of Nutrition 20 (2000) 431-456.

26. Angela A., Rivellese A. M., Bengt Vessby, Matti Uusitupa - Effects of dietary saturated, monounsaturated and n-3 fatty acids on fasting lipoproteins, LDL size and post-prandial lipid metabolism in healthy subjects., Atherosclerosis 167 (2003) 149-158.

27. HMSO U. - Department of Health. Nutritional aspects of cardiovascular disease, Report on Health and Social Subject 46 (1994) 37-46.

\title{
TÓM TẮT
}

\section{THÀNH PHẦN AXIT BÉO BAO GỒM ĐỒNG PHÂN DẠNG TRANS CỦA MỘT SỐ LOẠI BÁNH QUY BÁN Ở THỊ TRƯỜNG VIẸT NAM}

\author{
Hoàng Quốc Tuấn ${ }^{1,2, *}$, Vũ Hồng Sơn ${ }^{1}$, Nguyễn Thị Minh Tú ${ }^{1}$ \\ Viện Công nghệ sinh học và Công nghệ thực phẩm, Đại học Bách khoa Hà Nội \\ ${ }^{2}$ Đại học Tài nguyên và khoa học đời sống, \\ Cục Thưc phẩm khoa học và Công nghệ, Viện Khoa học thực phẩm, Vienna, Áo \\ "Email: tuanhqibft@gmail.com ; tuan.hoangquoc@hust.edu.vn
}

Trong nghiên cứu này, thành phần axit béo bao gồm axit béo dạng trans của một số loại bánh qui được sản xuất bởi công ty sản xuất bánh kẹo Việt Nam và các sản phẩm nhập khẩu được xác định bằng phương pháp sắc kí khí. Axit palmistic và oleic là hai loại axit chủ yếu, với nồng độ được xác định tuần tự là $21 \%$ đến $52 \%$, và $23 \%$ đến $43 \%$, tiếp theo là các loại axit linoleic, lauric, và myristic. Thành phần của axit béo bảo hòa, axit béo không no dạng đơn, và axit béo không no dạng đa được xác định tuần tự là $37-75 \%, 18-43 \%, 0,4-26 \%$ so với tổng số axit béo. Axit béo dạng trans được tìm thấy trong phần lớn các mẫu được phân tích, trừ các mẫu B3, B13, B17, B24, và thành phần xác định được từ $0,07 \%$ to $7,16 \%$. Kết quả nghiên cứu cho thấy, chất béo được sử dụng trong các mẫu bánh qui đã được phân tích là từ nhiều nguồn khác nhau, và có một số mẫu có hàm lượng thành phần axit béo dạng trans cao.

Tù khóa: axít béo dạng trans, bánh quy, thành phần axít béo. 